\title{
Victims of the Pandemic? European Far-Right Parties and COVID-19
}

\author{
Jakub Wondreys and Cas Mudde* \\ Department of International Affairs, University of Georgia, Athens, GA, USA \\ ${ }^{*}$ Corresponding author. Email: mudde@uga.edu
}

\begin{abstract}
It has become received wisdom that the pandemic has "exposed" the political incompetence of far-right parties in government and that far-right parties in opposition have become its (first) "victims." This is largely based on the generalization of one or two individual cases-most notably US president Donald Trumpwho is the exception rather than the rule. This article provides a comparative analysis of far-right responses to the COVID-19 pandemic within the European Union. Based on theoretical insights from previous research, we expect the responses to reflect the main ideology and the internal heterogeneity of the contemporary far right as well as to show the increasing mainstreaming of its positions. We analyze four different, but related, aspects: (1) the narratives about COVID-19 from far-right parties; (2) the proposed solutions of far-right parties; (3) the electoral consequences of the pandemic for far-right parties; and (4) the success of far-right parties in dealing with the pandemic. Finally, in the discussion we shortly look ahead at the possible consequences of a highly likely second outbreak of COVID-19.
\end{abstract}

Keywords: nationalism, far right; COVID-19; pandemic; Europe

\section{Introduction}

Given the recent obsession with "populism," which increasingly has become a (problematic) shorthand for "far right," it should have surprised few people that the combination of "populism" and the COVID-19 pandemic has led to a flurry of public speculation. By now, it is almost received wisdom that the pandemic has "exposed" the political incompetence of "populists" in government, while "populists" in opposition are COVID-19's (next) "victims" (Betz 2020a; English 2020). Most of this speculation is based on the generalization of one or two individual cases-most notably US president Donald Trump-who is the exception rather than the rule.

This article provides a comparative analysis of far-right responses to the COVID-19 pandemic in Europe. It focuses primarily on the main far-right parties in the broader European Union (EU), with some references to other far-right parties and politicians in other countries, notably Brazil and the US. Based on the theoretical framework presented by one of the authors, in his recent book The Far Right Today (Mudde 2019a), we expect the responses to reflect the main ideology and the internal heterogeneity of the contemporary far right as well as show the increasing mainstreaming of its positions.

In the next section, we will shortly lay out the characteristics of the "fourth wave" of the postwar far right and develop some expectations towards their response to and the effects of COVID-19. We

\footnotetext{
(C) The Author(s), 2020. Published by Cambridge University Press on behalf of Association for the Study of Nationalities. This is an Open Access article, distributed under the terms of the Creative Commons Attribution-NonCommercial-ShareAlike licence (http://creativecommons.org/ licenses/by-nc-sa/4.0/), which permits non-commercial re-use, distribution, and reproduction in any medium, provided the same Creative Commons licence is included and the original work is properly cited. The written permission of Cambridge University Press must be obtained for commercial re-use.
} 
will then analyze four different, but related, aspects. First, we discuss the narratives about COVID19 from far-right parties, in other words their discourse on the character and cause of the virus. Second, we compare the proposed solutions of far-right parties. Third, we explore the electoral consequences of the pandemic for far-right parties. And, fourth, we assess the success of far-right parties in dealing with the pandemic. Finally, in the discussion we shortly look ahead at the possible consequences of a highly likely second outbreak of COVID-19.

\section{The Fourth Wave: Heterogeneity and Mainstreaming}

In his groundbreaking 1988 article, the German political scientist Klaus von Beyme distinguished three waves of "right-wing extremism" in postwar Western Europe. The first wave, roughly in the first fifteen years after the Second World War, was defined by neo-fascism, with no successful political parties outside of the Italian Social Movement (MSI). The somewhat amorphous second wave, roughly between 1960 and 1980, was characterized by "right-wing populist" movements and parties, ranging from the French Poujadists to the German National Democratic Party (NPD). The third wave, starting in 1980 and defined as "right-wing extremism," was the most successful so far, in both electoral and political terms.

It was during the third wave that both academic and public interest in the far right exploded, and parties and politicians like the Austrian Freedom Party (FPÖ) and Jörg Haider as well as the National Front (FN) and Jean-Marie Le Pen became household names. The third wave was characterized by the electoral breakthrough but political marginalization of the far right (Mudde 2019a). Far-right parties were getting into national parliaments, but were kept out of (national) governments, through formal and informal cordon sanitaires (see Akkerman and Rooduijn 2014). Most of the parties also positioned themselves as outsiders to the system, uninterested in governing with the "establishment" parties. And even those that did, often kept "one foot in government and one foot out" (Zaslove 2012).

The most successful were the populist radical right parties, which combined nativism, authoritarianism, and populism (Mudde 2007). Nativism is a xenophobic form of nationalism, which wants states to be inhabited exclusively by "natives" and considers "non-natives" or "aliens" as a threat to the nation-state. It is best captured in the slogan that became infamous during violent protests in the streets of East German cities in the early 1990s: "Germany for the Germans, foreigners out!" Authoritarianism is the idea that only a strong state can and should prevent chaos, using a variety of measures, including large police forces, tough penalties, and the prioritization of discipline in education and upbringing. Populism, finally, is a thin-centered ideology that considers society to be ultimately separated into two homogenous and antagonistic groups: "the pure people" and "the corrupt elite," and argues that politics should be an expression of the volonté générale (general will) of the people (Mudde 2004).

At the beginning of the $21^{\text {st }}$ century, most notably in the wake of the terrorist attacks of $9 / 11$, the political context changed significantly, and so did the position of the far right. As socio-cultural issues started to dominate political debates, and the political mainstream moved to the right in terms of immigration and security, far-right issues and parties became increasingly mainstreamed and normalized (Mudde 2019a). In this fourth wave, far-right parties are no longer political challengers or outsiders, they are government parties, coalition parties, or at least Koalitionsfähig (acceptable for coalition formation). While the populist radical right was always more pathological normalcy than normal pathology (Mudde 2010), in several countries they have become the political mainstream, rather than a radicalization thereof-including in large countries outside of Europe, like Brazil, India, and the United States.

The fourth wave of the far right is characterized through (at least) two features that are of particular relevance to the far-right response to COVID-19: heterogeneity and mainstreaming. First, given the internal heterogeneity of the far right, we expect neither one uniform response to the crisis, nor one uniform effect of it. Specifically, we expect the government-opposition distinction to be particularly important to the difference between responses and effects. Second, as the far right is 
increasingly mainstreamed, if not the mainstream itself, we expect less pronounced differences between far-right responses and effects and those of mainstream parties. Third, and final, we do expect the far right's response to COVID-19 to be somewhat uniformly in line with its core ideologies of nativism, authoritarianism, and populism.

\section{Far-Right Discourses on COVID-19}

There has been a lot of emphasis on the denial or minimalization of the danger and threat of COVID-19 by far-right (and more broadly populist) politicians in the international media. Most of these pieces focus primarily, if not exclusively, on U.S. President Trump, at times also including Brazilian President Bolsonaro. However prominent they might be, Bolsonaro and Trump are exceptions rather than the norm. Most European far-right parties were quick to point to the danger of the virus (Betz 2020a, Meyer 2020), ${ }^{1}$ to the point of outright alarmism, although many started to walk that back after the number of cases had peaked, and some even started to spread misinformation.

A good example of that trajectory is Matteo Salvini and his League party in Italy, the first hit, and second hardest hit, country in the European Union. In line with its nativism, the League initially saw the "foreign" virus as a major threat-some local leaders referred to it as the "Chinese virus" (il Messaggero, February 21, 2020), but with time party opinions on COVID-19 started to fluctuate a lot, including across different regions. Arguably the key factor was that the most affected regions in Italy were governed by the League (Lecca 2020). Consequently, the party went from Salvini's alarmist appeals to close the borders and ban the Chinese New Year-after the first two cases in the country, which were two Chinese tourists in Rome-to claims that the virus was not that bad by the League governor of the hardest-hit province, Lombardy (Fanpage.it, February 27, 2020).

Several parties emphasized the Chinese origins of the virus, although few used Trump's infamous term "Chinese virus." Some did use the pandemic to point out not just the inferiority of the Chinese, but also the superiority of the own nation. For instance, the League governor of Veneto, Luca Zaia, underlined the presumed superiority of the Italians over the Chinese in terms of personal hygiene and cleanliness (tgcom24.it, February 28, 2020), while Polish far-right governmental party Law and Justice (PiS) declared, "it is clear today that thanks to the discipline and cohesion of Poland, our nation is victoriously fighting the coronavirus" (PiS, June 2, 2020). The worst example was VOX general secretary Ortega Smith, who, after contracting COVID-19, tweeted, "my 'Spanish antibodies' fight against the damn Chinese viruses." 2

However, for most far-right parties the Chinese roots of the virus did not give way to serious antiChinese (or broader anti-Asian) campaigns-Chinese and East Asians do not play an important role in European nativism, unlike in the US (Potok 2020). Still, the Hungarian governmental party Fidesz-Hungarian Civic Alliance (Fidesz) not only refrained from anti-Chinese rhetoric, it explicitly expressed solidarity with the Chinese fight against COVID-19 (Fidesz, March 2, 2020) and emphasized that everyone anywhere could get infected (Fidesz, April 11, 2020). This uncharacteristic openness towards non-EU foreigners is probably best explained by the close ties between the Orbán regime and the Chinese government.

Most parties also quickly linked COVID-19 to immigration in general, and "illegal" immigration in particular (see also Bieber in this special issue; Jansen 2020). Parties like Fidesz see immigration as the main cause of COVID-19. Orbán's chief security advisor, György Bakondi, claimed that "illegal migration has been a health problem so far, but it has reached a new level with the coronavirus epidemic" (Fidesz, March 27, 2020). And Jean-Paul Garraud, Member of the European Parliament (MEP) of the National Rally (RN), formerly National Front (FN), warned that illegal immigration and the intentions of the EU to reopen the borders will lead to a second wave of infections ( $R N$, July 2, 2020). Playing on longstanding racist prejudices, Marian Kotleba, leader of the neo-fascist Kotlebists-People's Party Our Slovakia (L'SNS) - claimed that, because of open borders, "Europe is full of illegal aliens of whose health conditions we don't know nothing about” (L'SNS, March 12, 2020). 
Far-right parties also linked the pandemic to ethnic minorities within their countries. From the AfD to the VB, they accused minority groups, in particular Muslims, of flaunting government policies and of thereby endangering the "native" population. In more "coded" language, RN leader Marine Le Pen expressed her support for a government curfew to enforce the measures, only to add that "there are a whole series of places where the police have the greatest difficulty in enforcing the confinement rules, it is a major danger"-a clear reference to multicultural areas (Le Figaro, March 19, 2020).

While both authoritarian leaders and liberal pundits have spoken about a "war on COVID-19" (Mudde 2020a), this authoritarian rhetoric is rarely found in the propaganda of far-right parties, not even those in power. One of the few people to use war language was Polish Prime Minister Mateusz Morawiecki, who said that all Poles "meet on the battlefield against coronavirus" (PiS, March $16,2020)$. In a more religious interpretation of the ultimate struggle, Greek Solution, referencing the place where Jesus was, according to the Bible, crucified, stated, "we stay home until our Golgotha is over. Along with all this, united we can hope for the 'Resurrection' of all Greeks!" (EL, April 4, 2020).

As was to be expected, far-right parties in opposition integrated the government response to COVID-19 into their populist discourse, blaming governments for responding too late, too slow, or too weakly (see also Meyer 2020). Two Flemish Interest (VB) parliamentary leaders even published a book on the topic, entitled the Corona Blunderboek (Corona Blunder Book). The authors list "the greatest blunders" that the Belgian and Flemish governments made, "from the minimalizing of the risk and danger in February and March to the current and ongoing fiasco with the face masks" (Pas and Janssens 2020). They accuse the government of underestimating the coronavirus, i.e. treating it as "just like the flu," bungling the communication with the population, and leaving the people, and particularly doctors and health workers, without essential protective gear and tests. ${ }^{3}$

Some parties and politicians took their rhetoric to more extreme levels, however. Spanish party VOX, for example, accused the left-wing Spanish government of a policy of "euthanasia" and threatened to sue the government for "criminal malfeasance" (Betz 2020d). Sweden Democrats (SD) leader Jimmie Åkesson demanded the resignation of state epidemiologist Anders Tegnell and called the government response "a massacre." In an interview with the newspaper Aftonbladet he stated, "thousands of people have died prematurely as a result of, I claim, serious misjudgments initially made about the power of this virus" (June 11,2020).

However, the same parties that criticized the government for doing too little and too late, also (often just a few weeks later) started to speak out against the alleged "anti-democratic" and "unconstitutional" nature of some of the government policies. For instance, after a rather docile start to the COVID-19 debate, in which it largely supported government policies, the Alternative for Germany (AfD) argued that freedom of speech was "the clearest victim of corona" (AfD Kompakt, April 7, 2020), echoed Edward Snowden that "corona-surveillance will survive the virus" (AfD Kompakt, April 3, 2020), and argued that the lockdown threatened both the country's economy and freedom (AfD Kompakt, April 22, 2020). Similarly, the FPÖ (April 9, 2020) claimed to have "prevented Kurz' surveillance state," claiming, bombastically, that they had "stopped - for the time being - the totalitarian black and green surveillance plans." Ironically, Europe's most extremist parliamentary party, Slovakia's L'SNS, was most critical of the country, admittedly strict, government's COVID-19 measures. Party leader Kotleba even went so far as to argue that the Slovak government used COVID-19 as an excuse to "enslave" the people (L'SNS, April 15, 2020).

While far-right parties in opposition criticized the government for doing too little, too late, those in government implicated the opposition in spreading the virus or frustrating the (excellent) government response. For instance, the Hungarian government targeted the mayor of Budapest for mismanaging the situation (Fidesz, April 4, 2020), while Polish Prime Minister Morawiecki argued that the opposition, "instead of taking care of peace and helping, threw sand in the modes" (PiS June 2, 2020). In Estonia, the EKRE went even further, claiming that the opposition Reform Party had intentionally helped the outbreak of the virus in an attempt to overthrow the government (UUED UUDISED, March 30, 2020). 
However, there is also a populist discourse that is shared by far-right parties in both opposition and government. This Eurosceptic discourse combines nativism and populism and accuses the EU of misusing the pandemic to undermine national sovereignty and push through new supranational measures. For instance, PiS chairman Jarosław Kaczyński claimed that COVID-19 has exposed the "weakness of the EU" and the "the importance of nation states" (Tilles 2020), while RN MEP Garraud stated, "for these frenzied and ultra-liberal globalist Europeanists, any pretext is good, even those relating to health issues, to try to implement their globalist and federalist vision of Europe" ( $R N$, May 27, 2020).

Of course, far-right parties also connected the COVID-19 pandemic to their particular pet peeves. For instance, in line with its anti-“gender ideology" obsession, VOX claimed that the International Women's Day demonstrations, which took place in many cities a week before the government declared a state of emergency, had "triggered" the pandemic in Spain. Ironically, the party was called out for organizing its own mass gathering in Madrid, on the same day, which led to the infection of many of the party leadership, including general secretary Ortega Smith and leader Santiago Abascal, and a humbling apology. VOX also argued that "separatist privileges" had weakened the COVID-19 response of the national government and that the pandemic once again showed that the country needed "real national unity" (Aguilera-Carnerero and Molas 2020).

Finally, there is the tricky issue of "fake news," which again gained most of its attention because of the situation in the US, in particular President Trump. Of course, by now, the term "fake news," as well as the whole issue of "disinformation," is part of the political battle. Hence, while many mainstream politicians accuse far-right politicians of spreading "fake news," many far-right parties do the same with regard to mainstream governments or parties. With some notable exceptions, farright parties were not actively spreading fake news, but several have expressed particularly open positions to fringe theories. First among them were Salvini, ${ }^{4}$ who propagated the Chinese biolab conspiracy theory, and Thierry Baudet, leader of the Dutch Forum for Democracy (FvD), who often seems to follow Trump's lead, by first pushing for more research into hydroxychloroquine and later arguing that that the virus would disappear "when the weather becomes nicer" ( $F v D$, March 22, 2020).

Regarding the conspiracy theory that COVID-19 was designed intentionally in a Chinese biolab, Marine Le Pen said it was "a question of common sense" that people wondered about this and that she herself had "no opinion on this subject" (Le Figaro, March 30, 2020). No doubt she was aware of the fact that 40 percent of RN supporters supported the conspiracy theory. At the same time, she called the French government the "biggest purveyor of fake news since the beginning of the crisis" (Betz 2020b). More vaguely, Polish prime minister Morawiecki said that Poles "must fight the disinformation epidemic" (PiS, March 2, 2020), but did not indicate the source of the alleged epidemic.

\section{Proposed Solutions}

In line with its nativism, and the declared link between COVID-19 and "illegal" immigration, all farright parties emphasized the importance of border control. While they appreciated the fact that almost all countries introduced border controls, or closed borders almost altogether, in the wake of the COVID-19 outbreak, many far-right parties were incensed that most again re-opened after the curve had flattened. For instance, RN MEP Garraud exclaimed, "the health crisis has demonstrated the fundamental interest of internal and external Schengen border controls in this area, logic would dictate that they continue. The exact opposite is the case!" ( $R N$, June 17, 2020). He later argued the re-opening of the EU borders would lead to a second wave of infections ( $R N$, July 2, 2020).

Several parties also used the opportunity to call for an abolition of political asylum. Finns Party (PS) MP Mari Rantanen criticized the Finnish government for, "even in the midst of the biggest crisis in our recent history caused by the coronavirus ... [having] the time and money to consider increasing the interests of asylum seekers," while DF leader Kristian Dahl tweeted, "Stopping corona also equals a stop for asylum seekers across the Danish border!" (March 17, 2020). Taking it 
a step further, Herbert Kickl, chairman of the FPÖ's parliamentary faction, called for the indefinite abolition of asylum law as well as border guard exercises and security zones in the crisis regions" (FPÖ, March 29, 2020).

Partly linked to this, many parties also argue that COVID-19 has shown the dangers of "globalization" and "neoliberalism" as well as emphasized the importance of the national state and the public sector (Bar-On and Molas 2020a). More specifically, they argue that it had exposed the dangers of the West's reliance on China for its supply chain. This was a particular hobby horse of the Dutch FvD and its leader Thierry Baudet. He even devoted a special episode of the party's YouTube "news program" to "the threat of China" (FvD Journaal, May 2, 2020). It included an interview with US ambassador to the Netherlands Pete Hoekstra, who, to Baudet's visible pleasure, used it to push through Trump's anti-China agenda.

Far-right parties are much more divided about authoritarian measures, such as a lockdown, the banning of large gatherings, the wearing of face masks, and the enforcing of social distancing. Many parties were initially (very) supportive of the common government directives in the country. For instance, Greek Solution (EL) responded, almost docilely, by stating, "The next twenty-five days are considered quite critical for the country and require us to show seriousness and patience, while we all follow the directive faithfully" (EL, April 4, 2020).

And in the countries where the government took a less stringent approach to the pandemic, farright parties were among the most vocal protagonists of face masks and testing. For instance, both Dutch far-right parties championed the use of face masks in their country, even teaming up with each other and some mainstream opposition parties to submit several (ultimately unsuccessful) parliamentary motions to "stimulate the wearing of face masks." Baudet made a "mini docu" on the topic, "Corona in the Netherlands," in which he criticized the government (parties) of underestimating the threat of the coronavirus and called for "testing, testing, testing" (FvD Journaal Special, April 6, 2020). Similarly, in Sweden, a country that has taken a "survival of the fittest" approach to COVID-19, the SD consistently called for mass testing (Wiggen 2020), while the FPÖ attacked the government claiming that the Chancellor's promise of "tests, tests, tests" remains "a dream" (FPÖ, April 14, 2020).

But while far-right parties often were among the first to argue in favor of a "lockdown," they were usually also among the first to argue that it should be lifted again. For instance, the Dutch FvD had called for a very strict "short lockdown" early on, but when the Dutch government enforced its "intelligent lockdown," several weeks later, the party increasingly criticized it for allegedly creating an "economic pandemic." It currently campaigns fanatically against the " 1.5 meter society," and has submitted several parliamentary motions to open most of the sectors (e.g. bars and restaurants, gyms) that remain closed.

This is largely in line with other far-right parties, including those in government, which stress the economic costs of the COVID-19 measures and push for a quick reopening of the country as well as significant state subsidies for, particularly small, businesses. For instance, the FPÖ initially supported strict(er) measures but now talks about "corona madness" that allegedly obscures real society problems such as the illegal migration (FPÖ, August 28, 2020). Several parties, including the AfD and VOX, organized or supported anti-lockdown protests (see Ariza 2020: 9; Reuters, August 26, 2020). And even Brothers of Italy (FdI) leader Giorgi Meloni, whose more moderate opposition has contrasted sharply with Salvini's radical opposition, speaks of a "hypocrisy circuit" that discriminates against Italians, by allegedly not enforcing the lockdown rules among immigrants.

There is a regional divide in the position on EU assistance, in which the far right (again) largely reflects mainstream parties in their country. So, where most European far-right parties complained about EU overreach, most notably those in the North and East, some parties in the South criticized the EU for not helping their (hardest-hit) countries. For instance, both the League and FdI argue that the EU has abandoned Italy in the face of the COVID-19 pandemic. Salvini, in his usual "colorful" language, accused the EU of being nothing more than a "lair of serpents and jackals" (Betz 2020c).

Opposition to EU financial solidarity with the South is particularly fierce in the North, from the Estonian Conservative People's Party (EKRE) in the East to the Dutch Party for Freedom (PVV) in 
the West. For instance, the Finns Party claimed that "the money of the Finnish people disappears into Rome like ashes in the wind (Suomen Uutiset, May 12, 2020). The AfD summarized the Northern position best: "who creates debts, should also pay for them" (AfD Kompakt, April 9, 2020). Many far-right parties also saw an EU power grab. As RN MEP Nicolas Bay stated, the EU wants "to use the current health crisis to further increase its budget" ( $R N$, April 17, 2020), while the AfD argued that the EU used the corona crisis "as a cover to introduce the EU debt union" (AfD Kompakt, May 2, 2020).

This was yet another way in which the far right response was very much in line with that of mainstream parties in their country-particularly in the self-styled "Frugal Four," four Northern European countries opposed to a significant economic aid to help mainly South European countries cope with the pandemic (Denmark, Finland, the Netherlands, and Sweden). For instance, Dutch Prime Minister Mark Rutte, who became dubbed "Mr. No" in the international media, defended a fairly similar position as most Northern far-right parties, including the Dutch ones, albeit without the overtly nativist discourse. And Denmark's Social Democratic Prime Minister Mette Frederiksen, who had come to power by largely adopting the DF's Eurosceptic and nativist positions, extended these positions to the negotiations (EURACTIV, July 10, 2020), while opposition to economic transfers has brought the PS and the Finnish mainstream right closer together again ( $E A$ WorldView, April 27, 2020).

\section{Electoral Consequences}

There has been much speculation about the electoral consequences of the COVID-19 pandemic. It is to be expected that governments would benefit from the crisis in the short term, following the classic "rally 'round the flag" effect theory (Mueller 1970). In short, this theory predicts boosts in government support in times of international crisis, including war, as these crises distract the public from other important issues and call for national solidarity. Indeed, it has been suggested that there is evidence of a "rally 'round the flag" effect of the pandemic (Bol et al. 2020; Schminke 2020; Yglesias 2020).

To assess whether the "rally 'round the flag" effect truly holds with regard to the pandemic, we analyzed the average support in polls for the governing parties of all $27 \mathrm{EU}$ member states since the beginning of the COVID-19 crisis, in other words from March to June. The data demonstrate that governing party support did increase in the polls, albeit it slightly and mainly at the beginning of the crisis. From March to April, government parties went from 18.5 to 19.5 average electoral support in the polls. However, as the pandemic continued, the increase slowed (1.2 percent increase from April to May) and by the beginning of June, it was almost back to the initial numbers (after a 3.3 percent decrease from May to June). Consequentially, if there was any "rally 'round the flag" effect caused by the pandemic, it was fairly small and short-lived (see also Hirsch and Gallardo 2020).

There are also large differences across the cases, as well as some possible general trends. For instance, the German CDU/CSU, experienced an over 10-point increase in support between March and June, which is a relative increase of almost one-third, but no other governing party came even close to these numbers, making Merkel's party the exception rather than the rule. A more general observation is that boosts in support are mainly visible in the case of senior coalition parties, less visible for single-party governments, and almost invisible for junior coalition parties.

Linked to the thesis that governing parties profit from the COVID-19 crisis is the expectation that opposition parties should lose. It has been suggested that far-right parties will lose even more because the health crisis distracts public attention from their core issues, such as immigration, and unite people in the fight against a common "enemy" that is not "another nation or group but an indiscriminate virus" (Bieber in this special issue, 1; also Mead 2020; Hutton 2020). However, other authors have suggested that, especially in the longer-term, the effects of the crisis on far right electoral success might not be as strong as suggested (Mudde 2020b) or could lead to a far right backlash (Bieber 2020; Gerbaudo 2020). 
As we have argued, we anticipate these effects not to be unilateral, given the heterogeneity within the far right political family. Even when putting aside the ideological, organizational, regional, and other differences between the parties (see Mudde 2019a), should the "rally 'round the flag" effect argument truly stand, we cannot expect the COVID-19 crisis to similarly affect far-right parties that govern alone, those that are in the coalition government, and those that are in opposition.

In general, at the beginning of the crisis, the far-right's average loss in the polls was only 0.6. After the initial decrease, far-right parties maintained their average levels of support from April to June. In other words, the far right is neither "the significant loser" (Samaras 2020) nor "the profiteers" of the pandemic" (Burni 2020). For the moment, they remain largely unaffected by the "crisis," as goes for most political parties. However, this speaks to the general electoral effect on far-right parties. Given their heterogeneity, we should also investigate the effect of the position of a far-right party in the party system on the electoral effects of the COVID-19 crisis. Consequentially, we divided far-right parties into three groups: (1) in government, (2) in the government coalition, and (3) in opposition.

The two far-right parties in government (in Hungary and Poland) both gained support in the polls at the beginning of the crisis, consistent with the "rally 'round the flag" theory (see Table 1). Fidesz maintained that level of support throughout the whole three-month period reported here, while PiS lost some between May and June, when the situation in Poland (and Europe) started to normalize. However, the presidential elections in Poland were held during that time (first round on June 28, second on July 12), which the party's candidate, the incumbent Andrzej Duda, managed to win. And while he did so narrowly, with just 51 percent in the second round, this was half a percent less than he had gained in the previous election in 2015. So, contrary to a common narrative, COVID-19 does not (always) expose the alleged incompetence of "populists" in power.

Second, support for far-right parties in coalition governments does not seem to change much in times of COVID-19. On average, these parties lost only 0.3 percent in the polls between March and June, with overall marginal monthly changes. When we look at individual cases, the Bulgarian IMRO-Bulgarian National Movement (BMPO) and EKRE lost 1 percent overall, while the Slovak We Are Family (Sme Rodina) went up and down by 1 percent to ultimately remain the same. ${ }^{5}$ The Slovenian Democratic Party (SDS), the only senior coalition member, remained stable, after 1 percent changes up and down. Given that almost all far-right parties are junior parties in their respective coalition governments, this is in line with the theoretical expectations of the "rally 'round the flag" effect.

The vast majority of far-right parties are in opposition, however. Their average support in polls experienced some decrease during the crisis, but still less than one percent on average (for the full list of parties, see Appendix 1). However, there are some visible differences in the polls between individual parties in opposition. More detailed analysis demonstrates that several parties experienced high losses, some losses, and no losses, while some parties gained support during the crisis.

In the first group we can count, for instance, the Dutch FvD, which experienced the worst downfall of all far-right parties, losing seven percent from March to June, which is probably mainly related to several party scandals. Though the other Dutch far-right party was also hit in the polls at

Table 1. Polling averages of far-right parties in March-June 2020, by government status

\begin{tabular}{lcccccc}
\hline & & \multicolumn{5}{c}{ Polling averages (in \%) } \\
\cline { 3 - 7 } Government status & Number of parties & March & April & May & June & Difference March-June \\
\hline Government & 2 & 47.0 & 49.0 & 49.0 & 47.5 & +0.5 \\
\hline Coalition & 4 & 15.3 & 15 & 15.8 & 15 & -0.3 \\
\hline Opposition & 24 & 12.1 & 11.3 & 11.1 & 11.3 & -0.8 \\
\hline
\end{tabular}

Source: Polls of Polls (Politico) 
the beginning of the crisis, the PVV bounced back later, possibly at the expense of the FvD, increasing its overall support by one percent in June. Several parties lost three to four percent between March and June, including the AfD, League, PS, and SD. The parties in opposition that gained some support are mostly smaller parties, including the Czech Freedom and Direct Democracy (SPD), the Polish Confederation, the Portuguese Enough (Chega), and the Italian FdI, mostly at the expense of the League. Finally, and importantly, there was almost no recognizable effect on some of the oldest far-right parties in opposition, such as FPÖ, RN, and VB.

In conclusion, and as hypothesized, there is no unilateral electoral consequence of the pandemic on far-right parties (for a similar finding, based on largely the same data, see Rooduijn 2020). Of the 31 far-right parties analyzed, 16 have lost points in the first, and more acute, phase of the crisis from mid-March to mid-April, while five have gained points, and 10 have experienced no change in the polls. The overall effect was marginal, within one percent on average, which is in line with the broader electoral effect, which, after a modest "rally 'round the flag" effect, quickly waned.

Government status has some effect on the electoral consequences of far-right parties during the pandemic. The two parties that govern alone have mostly gained in the polls, parties in government coalitions were not strongly affected by it, while those in opposition have experienced, on average, slight losses in the polls-but there were so many differences within this last group that one can hardly speak of a clear trend. Moreover, it is important to note that we are talking here about opinion polls, not election results, which means that almost all of these "changes," at least those smaller than 1.5 percent, fall within the polls' respective margins of error.

\section{Political Success}

By now, the dominant view in the international, and particularly Anglophone, media is that COVID-19 has exposed "the failure of populist leadership" (Aron and Holland 2020), because their response to the pandemic "has been to spew misinformation, minimize the threat and dodge accountability" (Diehl 2020). This view is largely based on the sui generis case of Donald Trump, although some commentators also point to Jair Bolsonaro, Boris Johnson, and Indian Prime Minister Narendra Modi (Ahmad 2020; Rachman 2020). All these countries have indeed been among the worst affected in the world and have been widely criticized for their government response to the pandemic. Hence, they fit the stereotype of "populism" as irresponsible politics, which has been popular since at least the first wave of populism in Latin America (see, for example, Sachs 1990).

Moreover, it has been argued that the far right's skepticism towards science and unwillingness to listen to experts, based again mostly on the example of Trump, should be particularly harmful in times of a pandemic, "when facts are not about the number of attendees at a presidential inauguration, but rather the life or death of individuals, including friends and relatives, [and] expertise becomes more important" (Bieber in this issue, 5). But in Europe, this stereotype does not hold. There seems to be little evidence of mismanagement of the pandemic in the two most pure farright (populist) regimes, Hungary and Poland. Moreover, while the situation in some of the aforementioned far right-led countries is bad, it is not much better in countries that do not have far-right parties in government, such as Belgium, France, or Sweden.

The few existing studies on the topic have not generally found any evidence of populist governments downplaying the pandemic. For instance, Brett Meyer (2020) found that 12 of the 17 populist governments in his dataset have taken the COVID-19 crisis seriously, while some farright parties in opposition have accused the government of not taking the crisis seriously enough (see also above). Similarly, Constantin Bosancianu and his (many) collaborators (2020) have not found any important differences in the number of total cases and deaths between countries with "populist" and non-populist leaders.

To properly evaluate the (in)competence of far-right parties in Europe to deal with the COVID19 crisis, we have conducted a basic comparative and empirical analysis. Before we discuss our 
findings, however, it is important to note that such analyses inevitably face significant difficulties and their conclusions have to be treated with even more caution than usual. First, the pandemic is still very much ongoing, with more and more European countries battling a second wave. Consequently, it is both difficult and premature to assess which policies have "worked." Second, and related, it is somewhat unclear which sort of indicators we should use to make such inferences. The simple number of cases or deaths will hardly tell us the complete story, considering some crucial differences between countries in terms of population, population density, amount of testing, political system, healthcare system, median age, and many other important variables. And third, the data which are used to make inferences about (non)successful dealing with the pandemic are very problematic. Moreover, each individual country has problems in terms of the accuracy of its data, but given that each country has specific problems, the comparability of the data is particularly problematic (Rankin et al. 2020).

Taking these and other potential issues into account, we selected several measures included in the Our World in Data COVID 19 dataset (Beltekian et al. 2020) to assess how different countries dealt with the pandemic and how successful they were. These measures are (1) the total number of positive cases in proportion to population, (2) the total number of deaths in proportion to the population, (3) the total number of deaths in proportion to the total number of cases; (4) the stringency index, which indicates the severity of adopted measures (see Hale et al. 2020); and, finally, (5) the total number of people tested in proportion to the population. In the second part of the analysis, we also look at the slope of the cases per population over time. The time span that is being used is from early March, the beginning of the crisis, to early August, the beginning of the second phase of the crisis.

These measures allow us to (tentatively) compare how successfully European countries have responded to the COVID-19 pandemic. We have included data from all EU member states that have a relevant far-right party in parliament (20 in total), as well as those without (seven). ${ }^{6}$ The countries with a relevant far-right party are further divided into the three groups we identified before: the far right in government, the far right in coalition, and the far right in opposition. Table 2 presents the averages of the selected measures for the four clusters of countries (the data for individual countries are reported in appendix 2).

The analysis shows little evidence for the received wisdom that far-right parties have responded incompetently to the pandemic, be that for far-right parties in government or far-right parties in coalition. In terms of cases (per population) and deaths (per population), the numbers were lower than for countries where the far right is in opposition, as well as for countries without far-right representation in parliament. On average, the two countries with far-right governments did have a higher number of deaths per cases, but this is caused solely by the high death rate in Hungarypresumably at least in part a consequence of the exceptionally low level of testing in the country (see below). That said, Hungary still had a lower death rate than Belgium, France, or Italy.

Table 2. COVID-19 data by role of far right (by country)

\begin{tabular}{lccccc}
\hline Far Right Role & $\begin{array}{c}\text { Cases per } \\
\text { Population (\%) }\end{array}$ & $\begin{array}{c}\text { Deaths per } \\
\text { Population (\%) }\end{array}$ & $\begin{array}{c}\text { Deaths per } \\
\text { Cases (\%) }\end{array}$ & $\begin{array}{c}\text { Stringency } \\
\text { Index }\end{array}$ & $\begin{array}{c}\text { Tests per } \\
\text { Population (\%) }\end{array}$ \\
\hline Government (N = 2) & 0.09 & 0.01 & 8.15 & 62.15 & 4.70 \\
\hline Coalition (N=4) & 0.13 & 0.01 & 3.19 & 52.65 & 6.45 \\
\hline Opposition (N = 14) & 0.36 & 0.03 & 6.93 & 60.53 & 10.94 \\
\hline $\begin{array}{l}\text { Extraparliamentary } \\
(\mathrm{N}=7)\end{array}$ & 0.36 & 0.01 & 3.03 & 60.38 & 23.83 \\
\hline
\end{tabular}

Source: Our World in Data (Beltekian et al. 2020) 
We need to be cautious not to draw too strong conclusions from these results, however. First, all far-right parties in (coalition) government are in Central and Eastern Europe, the least effected region of Europe, with the exception of the harder-hit Balkans. ${ }^{7}$ Second, countries with far-right (coalition) governments tested about half as many people as countries with the far right in opposition (mainly in Western Europe), and about as quarter as many people as countries that do not have a far-right party in parliament. Hungary tested the least, only 3.8 percent of its population, while Luxembourg tested the most, almost 60 percent. ${ }^{8}$

Finally, the stringency index demonstrates that there is not much difference between countries with far-right governments and far-right oppositions in terms of the severity of the adopted measures, with the former being only slightly more severe. This again does not support the popular narrative that incompetent "populist" governments failed to take the virus seriously, or even ridiculed it (the "just a flu" narrative), and, consequentially, did not take appropriate actions to fight it. While the severity of the measures was somewhat lower in countries with far-right parties in coalition, it is hard to assess whether this was the doing of the (mainly junior) far-right coalition partners. Moreover, given the overall low numbers of cases and deaths, it is possible that these measures were simply not necessary, especially given that the peak of the pandemics in these countries was relatively short-it started later and declined earlier than in the West. ${ }^{9}$

Successful political management of the pandemic can also be evaluated by looking at how effective governments were in slowing down the pace of the infections. In other words, we can observe how fast the number of total cases, proportional to the population, grew over time. A steeper slope suggests that the government was less successful in its approach to stop the spread of the virus. We compared the slopes of cases per population from March to August in all EU countries (see appendix 3).

The analysis mostly confirms the previous results. We see that the countries with far-right governments, Hungary and Poland, have not experienced much of a steady growth in terms of number of cases. In the case of Hungary, the line is almost flat, suggesting that the government's measures adopted to curb the spread of infections were successful-although, again, the extremely low level of testing might also play a role. In Poland, the situation is similar, with exception of some growth in cases in the second phase of the pandemic (roughly from mid-July), when the restrictive measures were almost completely relaxed.

Similarly, countries with far-right parties in coalition governments were arguably successful in slowing down the spread of infections as well. Notably, Slovakia and Slovenia were among the most successful countries in Europe, while Estonia, after some initial growth in March and April, managed to fairly quickly flatten the line and get the situation largely under control. The situation is slightly more complicated in Bulgaria, consistent also with the worse situation in the Balkans, but again the sharper increase in cases occurred mostly in the later phase of the pandemic, after the relaxing of restrictions.

In contrast, the number of cases was higher and increased faster in countries where the far right is in opposition, especially in Western Europe. Obviously, given that this category includes by far the largest number of countries, there is more internal variation. For instance, the line is almost flat in Greece or Finland, while very steep in Belgium, Spain, and Sweden. In general, then, countries with far-right parties in the opposition seem to be managing the pandemic somewhat less well, even those in the less-affected Central and Eastern European region (i.e. Croatia and the Czech Republic). Finally, countries with no far-right party in parliament mostly had a relatively (low) flat line, although one had a slight increase at the end (Romania), one a sharp increase at the beginning (Ireland), and one a sharp increase at both the beginning and the end (Luxembourg).

To be clear, this analysis does not provide conclusive evidence that far-right parties are better suited to deal with pandemics. Such a clear conclusion would require far more evidence, which might not even be possible to obtain from the data we have at disposition at this moment. For instance, the regional differences are fairly evident, yet difficult to explain in a simple way. Moreover, the fact that we only have a limited number of countries with far-right coalitions and governments, while a much 
larger group of countries in which far-right parties are in opposition, or not even in parliament, makes a comparative analysis with such a scope very difficult, if not impossible.

We mainly aimed to evaluate whether the widespread claims about the incompetence of the far right's dealing with COVID-19 are correct. Overall, the analyses presented here did not support these claims. In other words, we have not found any evidence that far-right governments and coalitions have been less capable in dealing with the pandemic than mainstream governments and coalitions. Once again, Trump is the exception rather than the rule of the global far right.

\section{Conclusion}

In this article we have analyzed the responses of Europe's main far-right parties to the COVID-19 pandemic in terms of both narrative and policies. We assumed that their responses would be motivated by their core ideological features-nativism, authoritarianism, and populism-but would differ based, most notably, on their position in the political system, in other words whether they were in power or in opposition. The analysis showed that all far-right parties used a strongly nativist narrative, linking the pandemic to immigration, immigrants, and ethnic minoritiesalthough few used a strong anti-Chinese discourse-and strongly supported the closing of borders, arguing that the pandemic showed that closing borders is possible and works.

But the far-right parties did differ on their authoritarianism and populism. Some commentators have argued that "the idea of a complete lockdown fits well with the authoritarian tendency of the farright, which often express praise for strong leaders who can ensure socio-political isolation for the purposes of reducing external threats to their totalitarian power" (Klein 2020). But while the far right is clearly authoritarian, its support for authoritarian measures is largely determined by its political power. While far-right parties in power used the pandemic to push through, at times draconian, authoritarian measures, most notably Viktor Orbán in Hungary, far-right parties in opposition were among the first and loudest to criticize the lockdown in their countries. Across the continent, they would accuse mainstream governments of abusing their power and threatening democracy.

Linked to this, populism played out very differently across the European far right. Parties in opposition used increasingly sharp populist rhetoric against the mainstream governments, in particular against the lockdown, but also against any mandatory anti-COVID-19 measures (from face masks to social distancing to corona apps). Even far-right parties that had been the first in their country to call for a lockdown often became the most ardent critics of a subsequent government lockdown. Pretending to defend the interests and opinions of the people against an out-of-touch elite, they argued for voluntary over mandatory measures and for a faster and more radical re-opening of the country.

Despite all the academic and public speculation over the political impact of the pandemic, the electoral consequences so far remain minimal. Except for a modest short-term "rally 'round the flag" effect, which applied to both mainstream and far-right parties in Europe, COVID-19 has had little electoral impact on (far-right) parties. Despite some minor monthly fluctuations, the electoral differences between March and June are minimal for all three categories of far-right parties (i.e. in government, in coalition, and in opposition). More importantly, almost all individual changes were within the margins of error of the polls. In short, the idea that the coronavirus pandemic has proven "a crisis too far for Europe's far-right outsiders" (Samaras 2020) is clearly premature at best.

While far-right leaders might have failed in other countries, this is not the case in Europe. In terms of cases and deaths (per population), countries with far-right (coalition) governments performed better than countries in which far-right parties are either in opposition or not in parliament. They did test far fewer people, however, which is the main explanation for the exceptionally high deaths per cases ratio, particularly of Hungary. Equally surprising, there were few differences in terms of the stringency of the COVID-19 measures that were implemented, with far-right party governments the most stringent by a small margin. Finally, the slope of cases (per population) was, in general, smaller and shorter in countries with far-right government 
participation, suggesting they responded better. While it is important to note that all of the countries with far-right government participation are in Central and Eastern Europe, the least affected area of Europe, countries with far right parties in government also did (slightly better) than countries in that region without far-right parties in government.

These findings can to some extent also help us better understand the results of the previous analyses, such as the absence of significant electoral party effects of the pandemic. The non-effect on support for far-right parties in government and in government coalitions might not just be caused by the "rally 'round the flag" effect, which overall has been modest and short-lived, but also by the fact that in general, the crisis was less severe in these countries and the governments responded quickly with stringent measures.

In conclusion, the analysis largely confirms our expectations. The narratives of far-right parties were largely in line with their ideological core, in particularly with their nativism. However, both their authoritarianism and populism were strongly affected by their position in the political system, with far-right parties in opposition often taking an explicitly anti-authoritarian position. This heterogeneity also came out in the electoral effects, although they were largely too small to truly differentiate. Finally, there was clear evidence of mainstreaming, with little differences in terms of (proposed and implemented) policies as well as electoral effects between far-right and mainstream parties.

Of course, all of these findings are both preliminary and rudimentary. First, most official dataon number of cases and deaths-come with great uncertainties. Second, we are still largely in the dark about both the virus and the best ways to fight it. As Catherine Fieschi (2020) has pointed out in her assessment of the effects of the crisis on mainly the Italian far right, "it will be very difficult to assert counterfactuals: 'it could have been so much worse' never quite cuts it, because it sounds too politically convenient." And third, much of Europe is experiencing a return of the pandemicseemingly a second wave-that could be even more consequential, particularly as more and more people are expressing "COVID-19 fatigue" and an unwillingness to accept new stringent measures. Consequently, the limited public health and political effects of the first COVID-19 wave might be completely usurped by the potentially much more significant effects of a second wave.

Several authors have already argued that far-right parties will be the big winners of the post-crisis period, whenever that might be, being able to profit from the looming economic crisis as well as COVID-19 fatigue (e.g. Betz 2020a; Bruni 2020; Bruno and Downes 2020). Some even predict an evil transformation of the far right, which will be even more extreme and dangerous. Paolo Gerbaudo (2020), for instance, predicts that Europe is awaiting "something much worse than the populist right of the 2010s: an extreme right using the whole arsenal of the red scare and rightwing authoritarianism to intimidate opponents and defend its interests from demands for meaningful economic redistribution."

While all is possible, as we have no idea what the second wave will bring, most "crises," whether real or perceived, have had at best moderate effects on European political systems-from the oil crisis of the early 1970s to the Great Recession of the early 2000s. Even the so-called "refugee crisis" of 2015 -16 was more a catalyst than a cause of an already ongoing transformation of the role of the far right in European politics (Mudde 2019b). Moreover, given the fundamental heterogeneity of the contemporary far right, it is highly unlikely that "the" far right will win or lose. Just like mainstream parties, which they increasingly reflect, some far-right parties might increase support, other might lose support, and most will be barely affected.

\section{Notes}

1 Fun fact, in Switzerland, Magdalena Martullo-Blocher, an MP for the Swiss People's Party SVP, was the first and only MP to wear a face mask in the Swiss parliament in early March. She was asked to leave by the president of the National Assembly so she would "not disturb" the debates (she was allowed to return for voting). One of her colleagues went so far as to suggest that an MP 
wearing a face mask might create the impression that "the situation is worse than it really is" (Betz 2020a).

2 He quickly deleted the tweet, after it caused a huge backlash, including from the Chinese embassy (Cadena SER, 14 March).

3 In fact, Belgium is the European country with the worst numbers.

4 Matteo Salvini made a wildly popular Facebook message allegedly watched 144 million times by January 31, 2020, in which he claimed that it had been invented in Chinese laboratories (Engel 2020).

5 The second far-right coalition member, National Front for the Salvation of Bulgaria (NFSB), was not mentioned in the polls.

6 All countries that do not have a far-right party in parliament fall in this category.

7 The causes of these regional differences are undoubtedly complex and well beyond the scope of this study.

8 Luxembourg (60\%) and Malta (30\%) are the main reasons for the size of the difference in testing between countries without far-right parties in parliament and the rest.

9 For instance, both Slovenia and Slovakia had one of the highest stringency index numbers (over 85) out of all countries in April.

\section{References}

Aguilera-Carnerero, Carmen, and Bàrbara Molas. 2020. “The Spanish right, COVID-19 and the 'socio-communism." In Radical Right-Wing Responses to COVID-19, edited by Tamir Bar-On and Bàrbara Molas. Stuttgart: Ibidem.

Ahmad, Talmiz. 2020. "Self-absorbed, uncaring, incompetent: COVID has exposed populist leaders for what they are." The Wire, June 29.

Akkerman, Tjitske, and Mattijs Rooduijn. 2014. "Pariahs or Partners? Inclusion and Exclusion of Radical Right Parties and the Effects of Their Policy Positions." Political Studies 63 (5): 1140-1157.

Ariza, Cristina. 2020. From the Fringes to the Forefront: How Far-Right Movements Across the Globe Have Reacted to Covid-19. London: Tony Blair Institute for Global Change.

Aron, Hadas, and Emily, Holland. 2020. "The Covid-19 crisis shows the failure of populist leadership in the face of real threats." LSE US Centre Blog, March 24. https://blogs.lse.ac.uk/usappblog/2020/03/24/the-covid-19-crisis-shows-the-failure-of-pop ulist-leadership-in-the-face-of-real-threats/ (Accessed August 30, 2020.).

Bar-On, Tamir, and Bàrbara Molas. 2020. “Introduction.” In Radical Right-Wing Responses to COVID-19, edited by Tamir Bar-On and Bàrbara Molas. Stuttgart: Ibidem.

Beltekian, Diana, Daniel Gavrilov, Charlie Giattino, Joe Hasell, Bobbie Macdonald, Edouard Mathieu, Esteban Ortiz-Ospina, Hannah Ritchie, and Max Roser. 2020. "Our World in Data COVID 19 dataset.” github.com/owid/covid-19-data/tree/ master/public/data (Accessed August 29, 2020.)

Betz, Hans-Georg. 2020a. “Coronavirus-19's victims: populism.” In Radical Right-Wing Responses to COVID-19, edited by in Tamir Bar-On and Bàrbara Molas. Stuttgart: Ibidem,.

Betz, Hans-Georg. 2020b. "Will France’s Marine Le Pen be a profiteer or victim of the pandemic?" In Radical Right-Wing Responses to COVID-19, edited by Tamir Bar-On and Bàrbara Molas. Stuttgart: Ibidem.

Betz, Hans-Georg. 2020c. “After COVID-19: Will Matteo Salvini lead Europe's radical right?” In Radical Right-Wing Responses to COVID-19, edited by Tamir Bar-On and Bàrbara Molas. Stuttgart: Ibidem.

Betz, Hans-Georg. 2020d. “Tilting at windmills: the Spanish radical populist right in times of COVID-19.” In Radical RightWing Responses to COVID-19, edited by Tamir Bar-On and Bàrbara Molas. Stuttgart: Ibidem.

Bieber, Florian. 2020. "Global Nationalism in Times of the COVID-19 Pandemic." Nationalities Papers. Published online ahead of print April 27, 2020. http://doi.org/10.1017/nps.2020.35

Bol, Damien, Marco Giani, André Blais, and Peter John Loewen. 2020. "The effect of COVID-19 lockdowns on political support: Some good news for democracy?” European Journal of Political Research. Published online ahead of print May 19, 2020. doi: 10.1111/1475-6765.12401.

Bosancianu, Constantin M., Kim Y. Dionne, Hanno Hilbig, Macartan Humphreys, Sampada KC, Nils Lieber, and Alex Scacco. 2020. "Political and social correlates of Covid-19 mortality." SocArXiv Papers, June 16. 10.31235/osf.io/ub3zd. (Accessed August 30, 2020.)

Bruni, Aline. 2020. "Profiteers of the pandemic? COVID-19 has not killed global populism." The Current Column, June 25. diegdi.de/en/the-current-column/article/covid-19-has-not-killed-global-populism (Accessed August 23, 2020.) 
Bruno, Valerio Alfonso and James F. Downes. 2020. "COVID-19 and the (temporary) fall of the populist radical right in European politics?” In Radical Right-Wing Responses to COVID-19, edited by Tamir Bar-On and Bàrbara Molas. Stuttgart: Ibidem.

Diehl, Jackson. 2020. “The Winners and Losers of Coronavirus's Test of Governance." The Washington Post, March 31.

Engel, Valerie. 2020. "Will the world be more tolerant after the COVID-19 pandemic?” In Radical Right-Wing Responses to COVID-19, edited by Tamir Bar-On and Bàrbara Molas. Stuttgart: Ibidem.

English, Otto. 2020. “Coronavirus' next victim: populism." Politico, March 18.

Fieschi, Catherine. 2020. "Europe's populists will try to exploit coronavirus. We can stop them.” The Guardian, March 17.

Gerbaudo, Paolo. 2020. "Coronavirus embarrassed Trump and Bolsonaro. But the global right will fight back.” The Guardian, April 1.

Hale, Thomas, Sam Webster, Anna Petherick, Toby Phillips, and Beatriz Kira. 2020. “Oxford COVID-19 government response tracker.” bsg.ox.ac.uk/research/research-projects/coronavirus-government-response-tracker (Accessed September 3, 2020.)

Hirsch, Cornelius, and Cristina Gallardo. 2020. "Polls show Europeans losing patience with governments: Leaders benefitted from a surge of support earlier in the crisis, but that is now starting to ebb away." Politico, March 19.

Hutton, Will. 2020. "Coronavirus won't end globalisation, but change it hugely for the better." The Guardian, March 8.

Jansen, Frank. 2020. “Wie Rechte das Coronavirus zur Hetze gegen Flüchtlinge benutzen.” Der Tagesspiegel, March 9.

Klein, Ofra. 2020. "How is the far right capitalizing on COVID-19?" In Radical Right-Wing Responses to COVID-19. Stuttgart: Ibidem.

Lecca, Tommaso. 2020. "Coronavirus, la giravolta della Lega: con la Cina porti chiusi, con il Nord "è una banale influenza." Europa Today, February 27. europa.today.it/attualita/coronavirus-giravolta-lega-cina-nord.html (Accessed August 30, 2020.)

Mead, Walter Russel (2020) “Will coronavirus kill populism?” WSJ Opinion, March 23. wsj.com/articles/will-coronavirus-killpopulism-11585004780 (Accessed August 30, 2020.)

Meyer, Brett. 2020. Pandemic Populism: An Analysis of Populist Leaders' Responses to Covid-19. London: Tony Blair Institute for Global Change.

Mudde, Cas. 2020a. "Wartime' coronavirus powers could hurt our democracy - without keeping us safe," The Guardian, March 24.

Mudde, Cas. 2020b. "Will the coronavirus 'kill populism?' Don't count on it," The Guardian, March 27.

Mudde, Cas. 2019a. The Far Right Today. Cambridge: Polity.

Mudde, Cas. 2019b. “The 2019 EU elections: moving the center," Journal of Democracy (30) 4, 20-34.

Mudde, Cas. 2007. Populist Radical Right Parties in Europe. Cambridge: Cambridge University Press.

Mudde, Cas. 2004. “The populist Zeitgeist," Government and Opposition 39 (4): 541-563.

Mueller, John E. 1970. “Presidential popularity from Truman to Johnson,” American Political Science Review 64 (1): 18-34.

Rachman, Gideon. 2020. “Coronavirus could kill off populism,” Financial Times, June 29.

Rankin, Jennifer, Stephen Burgen, Kim Willsher, and Shaun Walker. 2020. "Is comparing Covid-19 death rates across Europe helpful?” The Guardian, April 24.

Rooduijn, Matthijs. 2020. “Corona en radicaal-rechts populisme: einde van een tijdperk?” Stuk Rood Vlees, August 26. stukroodvlees.nl/corona-en-radicaal-rechts-populisme-einde-van-een-tijdperk (Accessed August 26, 2020.)

Sachs, J. 1990. "Social Conflict and Populist Policies in Latin America." In Labour Relations and Economic Performance, edited by Renato Brunetta and Carlo Dell'Aringad. International Economic Association Series. London: Palgrave Macmillan.

Samaras, Georgios. 2020. "Has the coronavirus proved a crisis too far for Europe's far-right outsiders?" The Conversation, July 29.

Schminke, Tobias Gerhart. 2020. "EU parliament projection: Corona rallies Europeans around the flag," Europe Elects, April 2. europeelects.eu/2020/04/02/rally-around-the-flag-corona-and-voting-behaviour-in-europe (Accessed August 30, 2020.)

Tilles, Daniel. 2020. "Kaczyński: coronavirus exposed 'EU's weakness' and Polish opposition 'does not accept democracy'." Notes from Poland, April 16.

Von Beyme, Klaus. 1988. "Right-wing extremism in post-war Western Europe," West European Politics 11 (2): 1-18.

Wiggen, Mette. 2020. "Gender and mainstreaming in the era of COVID-19: Swedish exceptionalism \& the radical right." In Radical Right-Wing Responses to COVID-19, edited by Tamir Bar-On and Bàrbara Molas. Stuttgart: Ibidem.

Yglesias, Matthew. 2020. “Trump's coronavirus poll bump, explained,” VOX, March 31. www.vox.com/2020/3/31/21199702/ rally-round-the-flag-coronavirus (Accessed August 30, 2020.)

Zaslove, Andrej. 2012. "The populist radical right in government: The structure and agency of success and failure." Comparative European Politics 10 (4): 421-448.

\section{Primary Sources}

AfD-Kompakt, magazine for Alternative for Germany members, available at afdkompakt.de.

$E L$, official website of Greek Solution, available at elliniki-lisi.gr.

Fidesz, official website of Fidesz-Hungarian Civic Alliance, available at fidesz.hu. 
FvD Journaal, YouTube "news magazine" for Forum for Democracy, available at youtube.com/channel/UC9H9K7oSpte0uW BofdW4UiA.

FPÖ, official website of ustrian Freedom Party, available at fpoe.at.

L'SNS, official YouTube channel of L'SNS, available at youtube.com/channel/UCFnpS4i3Dv5_gVmUxbLrsiQ.

Pas, Barbara and Chris Janssens (2020) Corona Blunderboek. Brussels: Egmont.

$P i S$, official website of Law and Justice, available at pis.org.pl.

$R N$, official website of National Rally, available at rassemblementnational.fr.

UUEDUUDISED, news outlet of Estonian Conservative People's Party, available at uueduudised.ee.

Appendix 1: Poll Averages of far-right parties (by party)

\begin{tabular}{|c|c|c|c|c|c|c|}
\hline \multirow[b]{2}{*}{ Country } & \multirow[b]{2}{*}{ Party } & \multirow[b]{2}{*}{ Status } & \multicolumn{4}{|c|}{ Voting Intention } \\
\hline & & & 10-Mar & 10-Apr & 10-May & 10-Jun \\
\hline Austria & FPO & Opp & 12 & 11 & 11 & 12 \\
\hline Belgium & VB & Opp & 26 & 26 & 26 & 26 \\
\hline \multirow[t]{3}{*}{ Bulgaria } & BMPO & Gov Coal & 5 & 5 & 5 & 4 \\
\hline & Volya & Opp & 2 & 2 & 2 & 1 \\
\hline & Attack & Opp & 2 & 1 & 1 & 1 \\
\hline Croatia & DPMŠ & Opp & 13 & 12 & 12 & 13 \\
\hline Czech Rep. & SPD & Opp & 5 & 6 & 7 & 7 \\
\hline Cyprus & ELAM & Opp & 5 & 5 & 5 & na \\
\hline \multirow[t]{2}{*}{ Denmark } & DF & Opp & 8 & 7 & 7 & 6 \\
\hline & NB & Opp & 3 & 3 & 3 & 5 \\
\hline Estonia & EKRE & Gov Coal & 18 & 17 & 18 & 17 \\
\hline Finland & Ps & Opp & 22 & 20 & 18 & 18 \\
\hline France & $\mathrm{RN}$ & Opp & 27 & 26 & 26 & 26 \\
\hline Germany & AfD & Opp & 12 & 10 & 10 & 9 \\
\hline Greece & $\mathrm{EL}$ & Opp & 6 & 4 & 5 & 4 \\
\hline \multirow[t]{2}{*}{ Hungary } & Fidesz & Gov & 50 & 52 & 52 & 52 \\
\hline & Jobbik & Opp & 10 & 9 & 8 & 7 \\
\hline \multirow[t]{2}{*}{ Italy } & Lega & Opp & 30 & 29 & 27 & 27 \\
\hline & Fdl & Opp & 13 & 13 & 14 & 15 \\
\hline \multirow[t]{2}{*}{ Netherlands } & FvD & Opp & 18 & 15 & 11 & 11 \\
\hline & PVV & Opp & 15 & 12 & 16 & 15 \\
\hline \multirow[t]{2}{*}{ Poland } & Pis & Gov & 44 & 46 & 46 & 43 \\
\hline & Confederation & Opp & 8 & 8 & 9 & 9 \\
\hline Portugal & Chega & Opp & 5 & 6 & 5 & 5 \\
\hline Romania & PRM & Opp & 2 & 2 & 2 & 2 \\
\hline \multirow[t]{2}{*}{ Slovakia } & SR & Gov Coal & 8 & 9 & 10 & 9 \\
\hline & LSNS & Opp & 8 & 8 & 8 & 9 \\
\hline
\end{tabular}




\begin{tabular}{|c|c|c|c|c|c|c|}
\hline \multirow[b]{2}{*}{ Country } & \multirow[b]{2}{*}{ Party } & \multirow[b]{2}{*}{ Status } & \multicolumn{4}{|c|}{ Voting Intention } \\
\hline & & & 10-Mar & 10-Apr & 10-May & 10-Jun \\
\hline \multirow[t]{2}{*}{ Slovenia } & SDS & Gov Coal & 30 & 29 & 30 & 30 \\
\hline & SNS & Opp & 4 & 4 & 4 & 3 \\
\hline Spain & Vox & Opp & 16 & 14 & 14 & 14 \\
\hline Sweden & SD & Opp & 22 & 20 & 19 & 19 \\
\hline Average & & & 14.5 & 13.9 & 13.9 & 14.0 \\
\hline
\end{tabular}

Source: Polls of Polls (Politico)

Appendix 2: COVID-19 data by role of far right and country

\begin{tabular}{|c|c|c|c|c|c|}
\hline Country & $\begin{array}{c}\text { Cases per } \\
\text { Population (\%) }\end{array}$ & $\begin{array}{c}\text { Deaths per } \\
\text { Population (\%) }\end{array}$ & $\begin{array}{l}\text { Deaths per } \\
\text { Cases (\%) }\end{array}$ & $\begin{array}{l}\text { Stringency } \\
\text { Index }\end{array}$ & $\begin{array}{l}\text { Population } \\
\text { Tested (\%) }\end{array}$ \\
\hline \multicolumn{6}{|c|}{ Far Right in Oppostion } \\
\hline \multicolumn{6}{|l|}{ (in parliament) } \\
\hline Austria & 0.24 & 0.01 & 3.3 & 56 & 10.7 \\
\hline Belgium & 0.65 & 0.09 & 13.2 & 65.5 & 16.4 \\
\hline Croatia & 0.14 & 0.00 & 2.8 & 57.1 & 3.2 \\
\hline Czech Republic & 0.17 & 0.00 & 2.1 & 52.1 & 7.1 \\
\hline Denmark & 0.25 & 0.01 & 4.3 & 64.5 & 30.6 \\
\hline Finland & 0.14 & 0.01 & 4.4 & 46.1 & 7.9 \\
\hline France & 0.30 & 0.05 & 15.3 & 69.1 & 6.9 \\
\hline Germany & 0.26 & 0.01 & 4.2 & 63.3 & 11.1 \\
\hline Greece & 0.06 & 0.00 & 3.8 & 63.2 & 6.3 \\
\hline Italy & 0.41 & 0.06 & 14.1 & 68.7 & 7.1 \\
\hline Netherlands & 0.35 & 0.04 & 10.4 & 61.2 & 7.0 \\
\hline Portugal & 0.52 & 0.02 & 3.3 & 71.9 & 17.3 \\
\hline Spain & 0.69 & 0.06 & 8.9 & 68.5 & 10.7 \\
\hline Sweden & 0.82 & 0.06 & 7 & 40.2 & na \\
\hline \multicolumn{6}{|c|}{ Far Right in Opposition } \\
\hline \multicolumn{6}{|c|}{ (extra parliamentary) } \\
\hline Cyprus & 0.14 & 0.00 & 1.5 & 72.4 & na \\
\hline Ireland & 0.54 & 0.04 & 6.6 & 66.1 & 13.6 \\
\hline Latvia & 0.06 & 0.00 & 2.5 & 54.4 & 11.4 \\
\hline Lithuania & 0.08 & 0.00 & 3.6 & 56.1 & 20.3 \\
\hline Luxembourg & 1.14 & 0.02 & 1.7 & 49.3 & 57.6 \\
\hline
\end{tabular}




\begin{tabular}{lccccc} 
Country & $\begin{array}{c}\text { Cases per } \\
\text { Population (\%) }\end{array}$ & $\begin{array}{c}\text { Deaths per } \\
\text { Population (\%) }\end{array}$ & $\begin{array}{c}\text { Deaths per } \\
\text { Cases (\%) }\end{array}$ & $\begin{array}{c}\text { Stringency } \\
\text { Index }\end{array}$ & $\begin{array}{c}\text { Population } \\
\text { Tested (\%) }\end{array}$ \\
\hline Malta & 0.23 & 0.00 & 0.9 & na & 32.9 \\
\hline Romania & 0.32 & 0.01 & 4.4 & 64 & 7.2 \\
\hline Far Right in Coalition & & & 3.3 & 51.8 & 4.4 \\
\hline Bulgaria & 0.19 & 0.01 & 2.9 & 46.7 & 9.7 \\
\hline Estonia & 0.16 & 0.00 & 1.2 & 58 & 5.1 \\
\hline Slovakia & 0.05 & 0.00 & 5.3 & 54.1 & 6.6 \\
\hline Slovenia & 0.11 & 0.01 & & 62.6 & 3.8 \\
\hline Far Right in Government & & & 12.8 & 61.7 & 5.6 \\
\hline Hungary & 0.05 & 0.01 & 3.5 & & \\
\hline Poland & 0.14 & 0.00 & & & \\
\hline
\end{tabular}

Source: Our World in Data

Appendix 3: The slope of COVID-19 cases (per population) by country

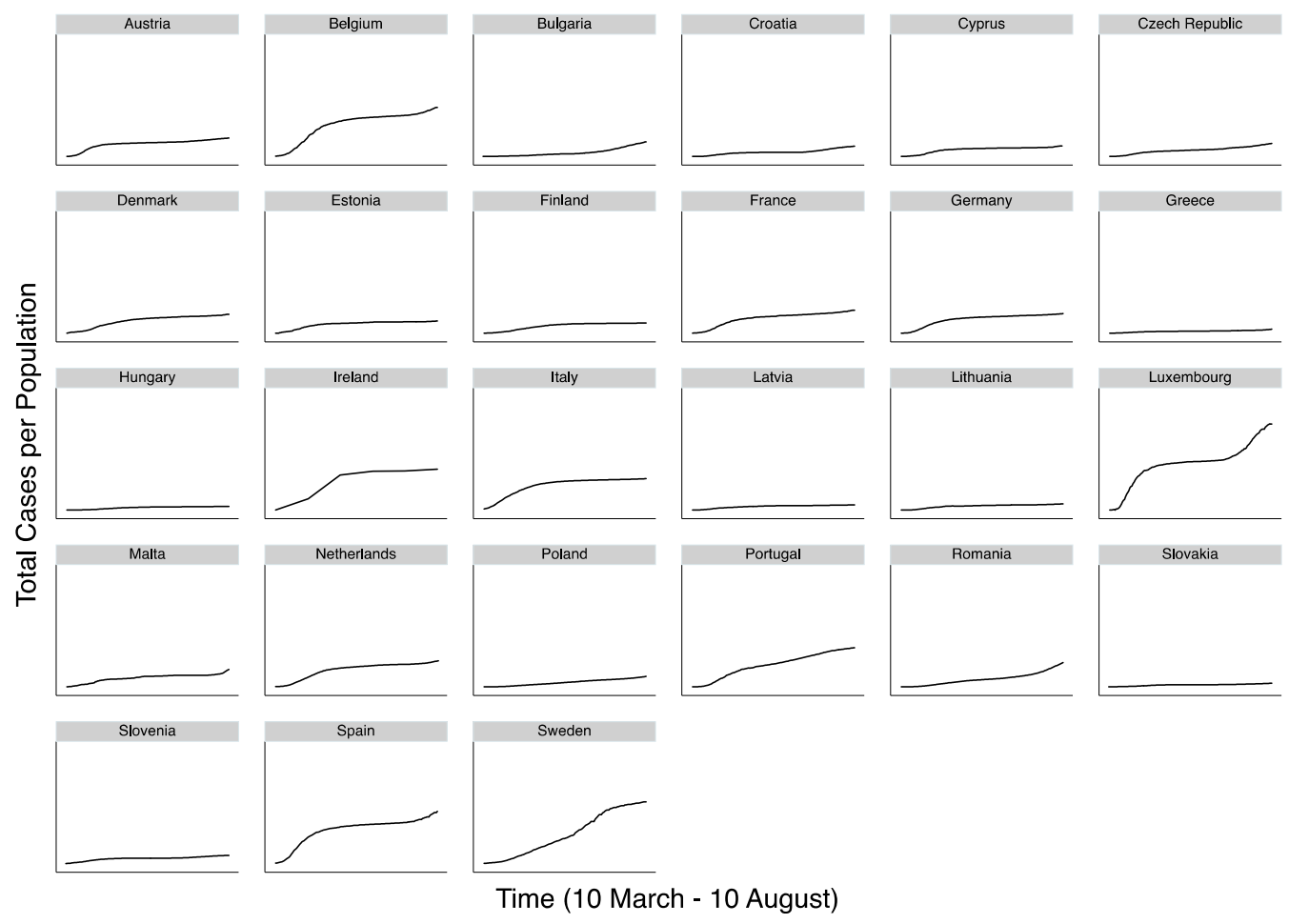

Cite this article: Wondreys, J. and Mudde, C. 2022. Victims of the Pandemic? European Far-Right Parties and COVID-19. Nationalities Papers 50: 86-103, doi:10.1017/nps.2020.93 